\title{
ZnO nanorod decorated by Au-Ag alloy with greatly increased activity for photocatalytic ethylene oxidation
}

\author{
Huishan Zhai, Xiaolei Liu, Zeyan Wang, Yuanyuan Liu, Zhaoke Zheng, Xiaoyan Qin, Xiaoyang Zhang, \\ Peng Wang *, Baibiao Huang \#
}

State Key Laboratory of Crystal Materials, Shandong University, Jinan 250100, Shandong, China

\section{A R T I C L E I N F}

\section{Article history:}

Received 17 February 2020

Accepted 26 March 2020

Published 5 October 2020

\section{Keywords:}

Surface plasmon resonance

$\mathrm{Au}-\mathrm{Ag}$ bimetallic alloy nanoparticles

Cooperative action

Effective carrier separation

\begin{abstract}
A B S T R A C T
In recent years, the preservation of fruits and vegetables in cold storage has become an issue of increasing concern, ethylene plays a leading role among them. We found $\mathrm{ZnO}$ has the effect of degrading gaseous ethylene, however its effect is not particularly satisfactory. Therefore, we used simple photo-deposition procedure and low-temperature calcination method to synthesize $\mathrm{Au}, \mathrm{Ag}$, and AuAg alloy supported $\mathrm{ZnO}$ to improve the photocatalytic efficiency. Satisfactorily, after ZnO loaded with sole $\mathrm{Au}$ or Ag particles, the efficiency of ethylene degradation was 17.5 and 26.8 times than that of pure $\mathrm{ZnO}$, showing a large increase in photocatalytic activity. However, the photocatalytic stability of $\mathrm{Ag} / \mathrm{ZnO}$ was very poor, because $\mathrm{Ag}$ can be easily photooxidized to $\mathrm{Ag}_{2} \mathrm{O}$. Surprisingly, when $\mathrm{ZnO}$ was successfully loaded with the AuAg alloy, not only the photocatalytic activity was further improved to 94.8 times than that of pure $\mathrm{ZnO}$, but also the photocatalytic stability was very good after 10 times of cycles. Characterization results explained that the Au-Ag alloy NPs modified $\mathrm{ZnO}$ showed great visible-light absorption because of the surface plasmon resonance (SPR) effect. Meanwhile, the higher photocurrent density showed the effective carrier separation ability in $\mathrm{AuAg} / \mathrm{ZnO}$. Therefore, the cooperative action of plasmonic AuAg bimetallic alloy NPs and efficient carrier separation capability result in the outstanding photoactivity of ethylene oxidation. At the same time, the formation of the alloy produced a new crystal structure different from $\mathrm{Au}$ and $\mathrm{Ag}$, which overcomes the problem of poor stability of $\mathrm{Ag} / \mathrm{ZnO}$, and finally obtains $\mathrm{AuAg} / \mathrm{ZnO}$ photocatalyst with high activity and high stability. This work proposes a new concept of using metal alloys to remove ethylene in actual production.
\end{abstract}

(C) 2020, Dalian Institute of Chemical Physics, Chinese Academy of Sciences. Published by Elsevier B.V. All rights reserved.

\section{Introduction}

In recent years, the noble metals have attracted great attention because of their outstanding physical, chemical and optical performances, which made them suitable as co-catalysts on some photocatalysts [1-8]. Most of them can be used as the electron-transfer active sites in photodegradation of dye [9], photocatalytic $\mathrm{H}_{2}$ production [10,11], $\mathrm{CO}_{2}$ reduction [12], transformation of green organic [13], thermocatalytic reduction of nitroaromatics in water [14] and so on. In particular, $\mathrm{Au}$ and Ag as common noble metals in our life are also widely investigated in photocatalytic academic research due to their unique surface plasmon resonance (SPR) [15-19]. The Au, Ag NPs under SPR-excitation have strong visible-light absorption,

\footnotetext{
* Corresponding author. E-mail: pengwangicm@sdu.edu.cn

\# Corresponding author. E-mail: bbhuang@sdu.edu.cn

This work was supported by the National Natural Science Foundation of China (51602179, 21333006, 21573135, and 11374190) and the Taishan Scholars Program of Shandong Province.

DOI: S1872-2067(19)63473-X | http://www.sciencedirect.com/science/journal/18722067 | Chin. J. Catal., Vol. 41, No. 10, October 2020
} 
thus they can be applied to solve the challenges in photocatalytic reactions such as narrow spectral response [15-19]. Furthermore, just like a semiconductor heterojunction can promote carrier separation [20-23], Au or Ag NPs can act as the active sites for capturing electrons, improving the separation of electron and hole pairs in photocatalytic system as well. Therefore, the Au or Ag supported materials have been also investigated in solving the problem of low quantum efficiency [24].

Bimetallic alloy is composed of two metals by a certain method. Recently, some studies have found that the semiconductors loaded with bimetallic alloy have many superior properties compared to that loaded with sole metal [25-29]. More importantly, they can complement each other to achieve a win-win situation. For example, $\mathrm{Au}-\mathrm{Cu}$ alloy supported on $\mathrm{TiO}_{2}$ is effective on photocatalytic $\mathrm{CO}_{2}$ reduction [30]. Among them, the selectivity in $\mathrm{CH}_{4}$ conformation owned to the $\mathrm{Cu}$ bonding to $\mathrm{CO}_{2}$ on $\mathrm{TiO}_{2}$, while the visible light photoresponse would be due to the surface plasmon band of $\mathrm{Au}$, illustrating $\mathrm{Au}$ and $\mathrm{Cu}$ in the $\mathrm{Au}-\mathrm{Cu}$ alloy have been put to the best utilization from each other [30]. In addition, Au-Pt alloy loaded on $\mathrm{WO}_{3}$ was used to strengthen hydrogen and oxygen generation owing to the mutual promotion of plasmonic function in $\mathrm{Au}$ and catalytic characteristic in Pt [15]. As we all know, Ag has similar plasmonic property as $\mathrm{Au}$. Therefore the $\mathrm{Au}$ and $\mathrm{Ag}$ in $\mathrm{Au}-\mathrm{Ag}$ alloy exhibit outstanding photocatalytic performances and synergistic effects which are superior to the pure metals under visible-light irradiation [31]. Au-Ag alloy loaded semiconductors have been applied to restore $\mathrm{CO}_{2}$ to fuels [32], heighten the photoelectrocatalytic properties [33], oxide of methanol selectively [34], and so on. In particular, we have found Au-Ag alloy played an important role in the degradation of the harmful gas ethylene recently.

Ethylene is produced in natural sources, plants and plant products. It has some harm on the storage life, development and growth of many ornamental crops, fruits and vegetables at extremely low concentration $[35,36]$. Some researchers have already realized the dangers of ethylene and looked for some ways to degrade it to keep fresh of fruits and vegetables. In the field of photocatalysis, many studies were focus on traditional $\mathrm{TiO}_{2}$ and $\mathrm{TiO}_{2}$-based photocatalysts [37-40], while new materials were rarely exploited on ethylene degradation. Actually there were only few new semiconductors had ethylene-oxidation function and their photocatalytic activity were very poor, such as $\mathrm{BiVO}_{4}$ and $\mathrm{In}_{2} \mathrm{O}_{3}-\mathrm{Ag}-\mathrm{Ag}_{3} \mathrm{PO}_{4}[41,42]$. Recently, we reported that $\mathrm{Fe}$-doped $\mathrm{WO}_{3}$ has the property of degrading ethylene [43], and the activity was greatly improved compared with previous studies. However, the ethylene cannot be completely mineralized to $\mathrm{CO}_{2}$. Therefore, it is urgent to find a highly active substance to deal with the ethylene. In this paper, we interestingly found $\mathrm{ZnO}$ had capability to oxide ethylene, but the activity was not so satisfactory. To improve the photocatalytic reaction rate greatly, Au-Ag bimetallic alloy NPs were loaded on the $\mathrm{ZnO}$. We systematically investigated the performance of single $\mathrm{Au}, \mathrm{Ag}$, and $\mathrm{Au}-\mathrm{Ag}$ alloy decorated on $\mathrm{ZnO}$, and we found the photocatalytic ethylene-oxidation activity of $\mathrm{ZnO}$ decorated by $0.8 \mathrm{wt} \%$ of $\mathrm{Au}-\mathrm{Ag}$ alloy was 94.8 times higher than that of pure $\mathrm{ZnO}$, while loaded by single $0.8 \mathrm{wt} \%$ of $\mathrm{Au}$ or Ag was only 17.5 or 26.8 times higher than that of $\mathrm{ZnO}$. These results confirm the Au-Ag alloy is superior to the single metal $\mathrm{Au}$ or $\mathrm{Ag}$ in ethylene-oxidation process. Therefore, the $\mathrm{Au}-\mathrm{Ag}$ alloy is the promising cocatalyst for ethylene oxidation to freshen fruits and vegetables in refrigeration storage.

\section{Experimental}

\subsection{Materials synthesis}

\subsubsection{ZnO nanorods}

The $\mathrm{ZnO}$ nanorods were prepared referring to the simple hydrothermal method [44]. Particularly, $0.4 \mathrm{~g} \mathrm{NaOH}$ was added to $60 \mathrm{~mL}$ ethanol under ultrasonic treatment until forming homogeneous $0.17 \mathrm{~mol} / \mathrm{L} \mathrm{NaOH} /$ ethanol solution. Then the solution was put into a Teflon tank of $100 \mathrm{~mL}$ capacity containing 2 $\mathrm{mmol} \mathrm{Zn}\left(\mathrm{CH}_{3} \mathrm{COO}\right)_{2} \cdot 2 \mathrm{H}_{2} \mathrm{O}$ and stirred for $30 \mathrm{~min}$. The tank was transferred into a stainless-steel autoclave and heated at $160{ }^{\circ} \mathrm{C}$ for $24 \mathrm{~h}$, the white powder was obtained after suction filtration with water and dried at $60{ }^{\circ} \mathrm{C}$. Then the $\mathrm{ZnO}$ powder was calcined at $400{ }^{\circ} \mathrm{C}$ for $1 \mathrm{~h}$ to remove the adsorbed ethanol.

\subsubsection{Au or Ag NPs loaded on $\mathrm{ZnO}$ nanorods}

The deposition of single Au NPs on the $\mathrm{ZnO}$ nanorods was synthesized via a photo-reduction method. Briefly, $0.15 \mathrm{~g} \mathrm{ZnO}$ was dispersed in $100 \mathrm{~mL} \mathrm{H}_{2} \mathrm{O}$ in a beaker. Then different volumes of $0.1 \mathrm{~mol} / \mathrm{L} \mathrm{HAuCl}_{4}$ were dripped into the system and stirred for $5 \mathrm{~min}$ in order to form a homogeneous mixture. Before irradiation, $1 \mathrm{~mL}$ methyl alcohol was added as the sacrificial agent. Then the mixture was irradiated for 30 min under the Xe lamp of $300 \mathrm{~W}$. Finally, the solid was filtered, dried at 60 ${ }^{\circ} \mathrm{C}$ and calcined at $400{ }^{\circ} \mathrm{C}$ for $1 \mathrm{~h}$ to make the Au NPs have a tightly integrated with the surface of $\mathrm{ZnO}$ and remove the adsorbed ethanol. The deposition of single Ag NPs on the ZnO nanorods was similar with these processes. The only difference was that $0.1 \mathrm{~mol} / \mathrm{L} \mathrm{HAuCl}_{4}$ was replaced with $0.1 \mathrm{~mol} / \mathrm{L} \mathrm{AgNO}_{3}$.

\subsubsection{Au-Ag bimetallic alloy NPs loaded on ZnO nanorods}

The Au-Ag bimetallic alloy NPs supported on $\mathrm{ZnO}$ nanorods were conducted with a co-photodeposition method. That is, a certain volume of $\mathrm{HAuCl}_{4}(0.5 \mathrm{wt} \% \mathrm{Au})$ and $\mathrm{AgNO}_{3}(0.3 \mathrm{wt} \%$ $\mathrm{Ag}$ ) were put together into the $\mathrm{ZnO}$ suspension under continuous stirring, and other reaction conditions were same as single $\mathrm{Au} / \mathrm{ZnO}$. The optimal $\mathrm{Au}-\mathrm{Ag}$ proportion on $\mathrm{ZnO}$ was $0.8 \mathrm{wt} \%$. Therefore, $0.8 \mathrm{wt} \% \mathrm{Au} / \mathrm{ZnO}$ and $0.8 \mathrm{wt} \% \mathrm{Ag} / \mathrm{ZnO}$ were also obtained as comparison by using the similar procedure.

\subsection{Characterization}

Morphologies were investigated by SEM (Hitachi S-4800) equipped with an EDS. XRD patterns were conducted on a Bruker AXS D8 diffractometer equipped with $\mathrm{Cu} K_{\alpha}$ radiation to reveal the crystal structure. The UV-vis DRS analyzes were recorded by Shimadzu UV-2550 spectrophotometer using $\mathrm{BaSO}_{4}$ as reflectance standard to explore the optical absorption. The TEM and HRTEM tests were performed with a JEOL JEM-2100F 
microscope to analyze the nanostructure and composition of the as-prepared AuAg/ZnO photocatalyst. XPS measurements were obtained using a Thermo ESCALAB 250XI, and the peak positions of various elements were calibrated by C $1 s(284.8$ $\mathrm{eV}$ ). Photoelectrochemical tests were measured by CHI-660C electrochemical workstation using a three-electrode system. The FTO glass coated catalyst was served as working electrode, Pt sheet as counter electrode and $\mathrm{Ag} / \mathrm{AgCl}$ as reference electrode. $0.2 \mathrm{~mol} / \mathrm{L} \mathrm{Na}_{2} \mathrm{SO}_{4}$ solution was used as the electrolyte. A 300 W Xe-arc lamp (CEL-HXF300, Beijing CEAU Light, China) was used for a light illuminant. The gas mixture was researched by means of the Shimadzu GC-2014C.

\subsection{Photocatalytic evaluation}

Photocatalytic oxidation of ethylene was measured in a quartz-covered reactor with $400 \mathrm{~mL}$ volume irradiated by a $300 \mathrm{~W}$ Xe lamp. $0.12 \mathrm{~g}$ photocatalyst was dispersed uniformly in the bottom of the container with a rotor. The reactor was then sealed by the quartz cover and injected into $0.5 \mathrm{~mL}$ ethylene under stirring. Before turning on the lights, the container was stirred in the dark for $2 \mathrm{~h}$ to make ethylene and air in the container mix evenly and attain the adsorption and desorption balance. When the balance was achieved, the reactor was illuminated on top of quartz cover and $50 \mu \mathrm{L}$ of gas mixture was sampled at regular intervals and tested by a gas chromatography. $C / C_{0}$ indicates the degradation percentage of ethylene, where $C$ is ethylene concentration at a specific time and $C_{0}$ is the initial concentration of ethylene. Stability of $\mathrm{AuAg} / \mathrm{ZnO}$ product was also investigated as follows: after each ethylene oxidation reaction, opened the cover and set aside 30 minutes to allow excess $\mathrm{CO}_{2}$ and $\mathrm{C}_{2} \mathrm{H}_{4}$ in the container to diffuse out. Then the reactor was sealed again to degrade a new $0.5 \mathrm{~mL}$ ethylene for another test under the same irradiation.

\section{Results and discussion}

\subsection{X-ray diffraction research of as-prepared nanocomposites}

The XRD spectra of obtained products are shown in Fig. 1. As can be seen from the left figure, the peaks of pure $\mathrm{ZnO}$ match well with the standard ZnO card (JCPDS, No. 70-2551). All of the diffraction peaks of the as-prepared samples after incorporation of noble metals are very identical to that of pristine $\mathrm{ZnO}$, with only small peak displacement in the part of the dotted line. From the magnified figure on the right and the Table 1 below, it can be seen that the $\mathrm{Ag} / \mathrm{ZnO}$ has two peaks at $37.99^{\circ}$ and $44.21^{\circ}$ while the peaks of $\mathrm{Au} / \mathrm{ZnO}$ at $38.30^{\circ}$ and $44.66^{\circ}$, which are in line with the Ag and Au standard cards (Fig. S1). It should be pointed out, however, the $\mathrm{AuAg} / \mathrm{ZnO}$ has peak locations $\left(38.22^{\circ}\right.$ and $\left.44.39^{\circ}\right)$ different from any one of single $\mathrm{Au}$ and $\mathrm{Ag}$, which are located between the peaks of $\mathrm{Au}$ and Ag. Similar consequence of Au-Ag alloy peak-displacement was also found in Fig. S1. This interesting phenomenon concludes that $\mathrm{Au}-\mathrm{Ag}$ alloy might come into being when $\mathrm{Au}$ and $\mathrm{Ag}$ are co-loaded on the $\mathrm{ZnO}$ and calcined at $400{ }^{\circ} \mathrm{C}$. Certainly, this conclusion needs to be proved further by the following results.

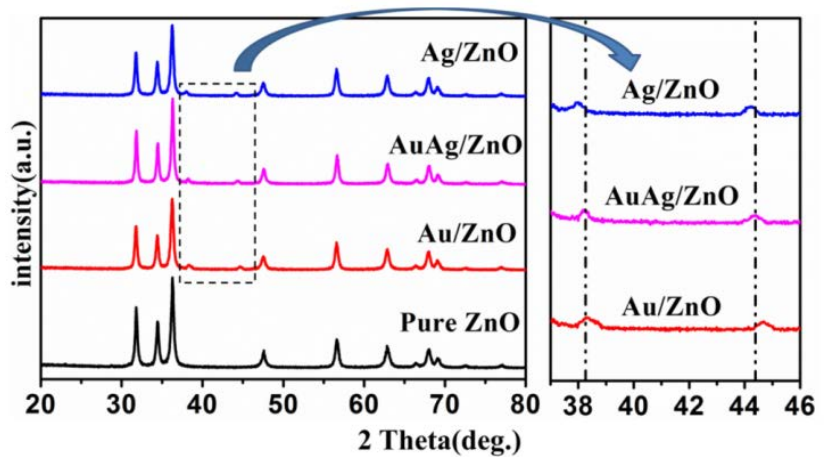

Fig. 1. The XRD patterns of the pure $\mathrm{ZnO}$ and $\mathrm{Au}, \mathrm{Ag}$, $\mathrm{Au}-\mathrm{Ag}$ alloy nanoparticles decorated on $\mathrm{ZnO}$ samples.

\subsection{EDS and elemental maps of nanocomposites}

Fig. 2a reveals the distribution and content of $\mathrm{C}, \mathrm{O}, \mathrm{Zn}, \mathrm{Au}$ and Ag. Among them, the source of $\mathrm{C}$ might be conductive plastic or the adsorbed $\mathrm{CO}_{2}$. As can be seen from Fig. $2 \mathrm{~b}$, the weight percentages of $\mathrm{Au}$ and $\mathrm{Ag}$ are, respectively, $0.55 \%$ and $0.21 \%$, which are close to the actual loading amount of $0.5 \%$ and $0.3 \%$. From Fig. 2c, we can see the overall distribution of $\mathrm{Au}$ and $\mathrm{Ag}$ elements are strongly uniform, illustrating that $\mathrm{Au}$ and $\mathrm{Ag}$ are evenly loaded on the surface of $\mathrm{ZnO}$.

\subsection{UV-vis diffuse spectroscopy}

To understand the different absorption of $\mathrm{Au}, \mathrm{Ag}$ and $\mathrm{AuAg}$ loaded $\mathrm{ZnO}$, the UV-vis diffuse reflectance spectra of $0.8 \mathrm{wt} \%$ $\mathrm{Au} / \mathrm{ZnO}, 0.8$ wt\% Ag/ZnO and 0.5 wt\% Au@0.3 wt\% Ag/Zno samples, together with that of pure $\mathrm{ZnO}$ nanorods, are investigated and exhibited in Fig. 3.

As can be observed in Fig. 3, pure $\mathrm{ZnO}$ has no absorption in the visible range, in agree with the reported band gap of $\sim 3.1$ $\mathrm{eV}$. However, the $\mathrm{Au}$ or $\mathrm{Ag}$ loaded $\mathrm{ZnO}$ displays increased visible light absorption owned to the surface plasmon resonance (SPR) effect of the metallic Au and Ag particles. Especially, there is a characteristic peak at around $550 \mathrm{~nm}$ of $\mathrm{Au} / \mathrm{ZnO}$ while $\mathrm{Ag} / \mathrm{ZnO}$ is approximately at $470 \mathrm{~nm}$, which is in accordance with the previous article $[31,45,46]$. Interestingly, when $\mathrm{Au}$ or $\mathrm{Ag}$ is replaced by the same amount of $\mathrm{Au}-\mathrm{Ag}$, it shows a broader and stronger peak at about $510 \mathrm{~nm}$ lying between the characteristic peaks of single $\mathrm{Au}$ and $\mathrm{Ag}$. These data further illustrate that when $\mathrm{Au}$ and $\mathrm{Ag}$ were co-loaded on $\mathrm{ZnO}$, they might form the Au-Ag alloy with the synergistic SPR effect, which can enhance the light absorption at $400-800 \mathrm{~nm}[32,33]$. And it is worth putting forward that the promoted light absorption generally along with the increased photocatalytic property.

\section{Table 1}

The two XRD peaks in the range of $37^{\circ}-45^{\circ}$ of $\mathrm{Ag} / \mathrm{ZnO}, \mathrm{AuAg} / \mathrm{ZnO}$ and $\mathrm{Au} / \mathrm{ZnO}$ samples.

\begin{tabular}{lcc}
\hline Sample & $2 \theta_{1}\left(^{\circ}\right)$ & $2 \theta_{2}\left(^{\circ}\right)$ \\
$\mathrm{Ag} / \mathrm{ZnO}$ & 37.99 & 44.21 \\
$\mathrm{AuAg} / \mathrm{ZnO}$ & 38.22 & 44.39 \\
$\mathrm{Au} / \mathrm{ZnO}$ & 38.30 & 44.66 \\
\hline
\end{tabular}


a)

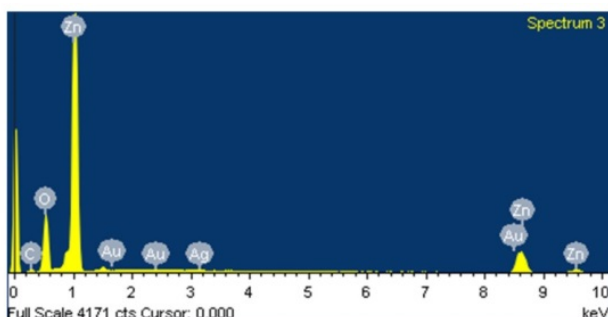

b)

\begin{tabular}{|c|cc|}
\hline Element & Weight $\%$ & Atomic $\%$ \\
$\mathrm{C}$ & 3.77 & 11.25 \\
$\mathrm{O}$ & 21.37 & 47.89 \\
$\mathrm{Zn}$ & 74.10 & 40.65 \\
$\mathrm{Au}$ & 0.55 & 0.18 \\
$\mathrm{Ag}$ & 0.21 & 0.04 \\
\hline Totals & $\mathbf{1 0 0 . 0 0}$ & \\
\hline
\end{tabular}

c)
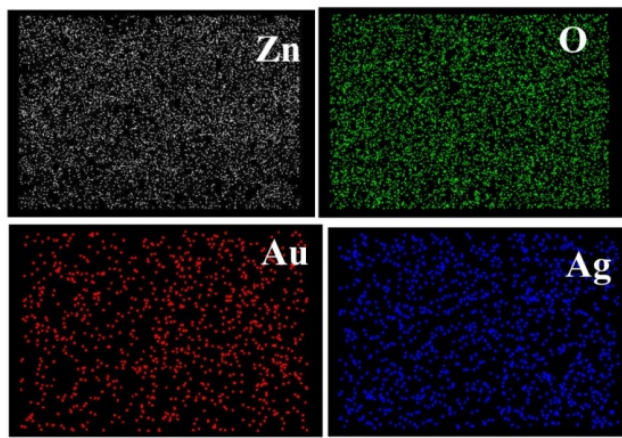

Fig. 2. (a, b) EDS spectra and (c) EDS elemental mapping analysis of 0 , $\mathrm{Zn}, \mathrm{Au}$, and $\mathrm{Ag}$ in the $\mathrm{AuAg} / \mathrm{ZnO}$ sample.

\subsection{SEM and TEM}

Fig. $4 \mathrm{a}$ and $\mathrm{b}$ are typical SEM images of the as-prepared $\mathrm{ZnO}$ and $\mathrm{AuAg} / \mathrm{ZnO}$. As can be seen, $\mathrm{ZnO}$ are nanorods with an average thickness of around $20 \mathrm{~nm}$. After loaded by Au-Ag alloy NPs, we can see from Fig. $4 \mathrm{c}$ that there are some small particles deposited on the surfaces and edges of nanorods. The key is that these nanoparticles have uneven size, some are big and some are small, with an average of $\sim 6 \mathrm{~nm}$ by calculating (see Supporting Information Fig. S2), and they are closely attached to the $\mathrm{ZnO}$ surfaces to have a better contact. Fig. $4 \mathrm{~d}$, e and $\mathrm{f}$ are the corresponding HRTEM images of $\mathrm{AuAg} / \mathrm{ZnO}$. The detected lattice fringes of $\mathrm{ZnO}$ are matching well with the (002) plane of

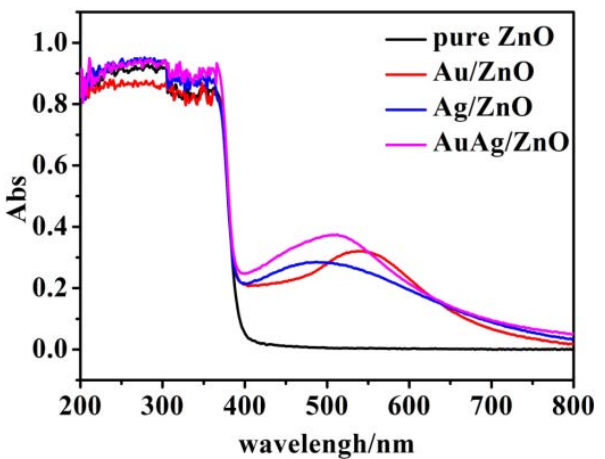

Fig. 3. UV-vis diffuse reflectance spectra of $\mathrm{ZnO}, \mathrm{Au} / \mathrm{ZnO}, \mathrm{Ag} / \mathrm{ZnO}$ and $\mathrm{AuAg} / \mathrm{ZnO}$ samples.
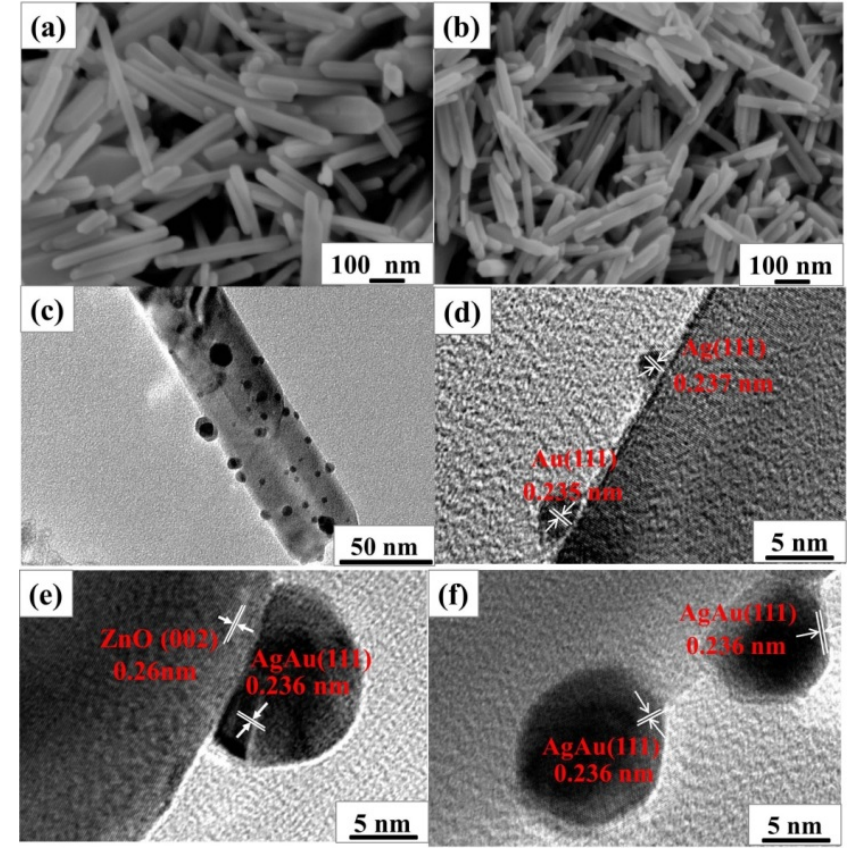

Fig. 4. (a) SEM of pure $\mathrm{ZnO}$, (b) SEM of $\mathrm{AuAg} / \mathrm{ZnO}$, (c) TEM of $\mathrm{AuAg} / \mathrm{ZnO}$, and (d, e, f) HRTEM images of AuAg/ZnO.

$0.26 \mathrm{~nm}$ (JCPDS, No. 70-2551). After a lot of detection, the $d$-spacing values of these small metal NPs (3-7 nm) are 0.235 $\mathrm{nm}(\mathrm{Au}(111)$ JCPDS 01-1172) and $0.237 \mathrm{~nm}$ (Ag(111) JCPDS 01-1164), one of the pictures is presented in Fig. 4d. However, the $d$-spacing values of these big metal NPs (10-15 nm) are all $0.236 \mathrm{~nm}$ (AgAu(111) JCPDS 65-8424), presented in Fig. 4e and 4f. The size of AuAg NPs coated on $\mathrm{ZnO}$ is larger than $\mathrm{Au}$ or $\mathrm{Ag}$ NPs due to Au-Ag alloy formation [32].

Besides, the information crisply exhibits that the $\mathrm{AuAg} / \mathrm{ZnO}$ photocatalyst possesses not only a distribution of the $\mathrm{Au}-\mathrm{Ag}$ alloy NPs but also the coexistence of unalloyed Au and Ag NPs. Similar phenomenon is also appeared in $\mathrm{Au}-\mathrm{Cu}$ alloy loaded on $\mathrm{TiO}_{2}$, that is, $\mathrm{AuCu} / \mathrm{TiO}_{2}$ sample consists of $\mathrm{Au}-\mathrm{Cu}$ alloy NPs together with independent $\mathrm{Au}$ and $\mathrm{Cu}$ NPs, which is difficult to avoid [30]. Anyway, this result further proves the formation of $\mathrm{Au}-\mathrm{Ag}$ alloy NPs in $\mathrm{AuAg} / \mathrm{ZnO}$ and its photocatalytic activity and stability are both satisfactory in the following tests.

\subsection{X-ray photoelectron spectroscopy study}

To obtain the surface chemical status of AuAg/ZnO before and after irradiation, X-ray photoelectron spectroscopy was carried out. Fig. $5 \mathrm{a}$ is the full spectra of $\mathrm{AuAg} / \mathrm{ZnO}$ sample before and after degradation, where the peaks for $\mathrm{Zn} 2 p$ and $01 s$ can be seen clearly. In Fig. 5b, the two peaks centered at 1021 $\mathrm{eV}$ and $1044 \mathrm{eV}$ are corresponding to the $\mathrm{Zn} 2 p_{3 / 2}$ and $\mathrm{Zn} 2 p_{1 / 2}$. There is no displacement of the peak position before and after the reaction, indicating that the chemical state of the $\mathrm{Zn}$ element has not changed. Similarly, as seen from Fig. $5 c$, the peaks of $\mathrm{AuAg} / \mathrm{ZnO}$ before degradation located at $529.5 \mathrm{eV}$ and 531.4 $\mathrm{eV}$ are indexed to lattice oxide and adsorbed oxygen [32]. After degradation, the peak of lattice oxide has no change, indicating $\mathrm{ZnO}$ did not change before and after reaction. However, the 

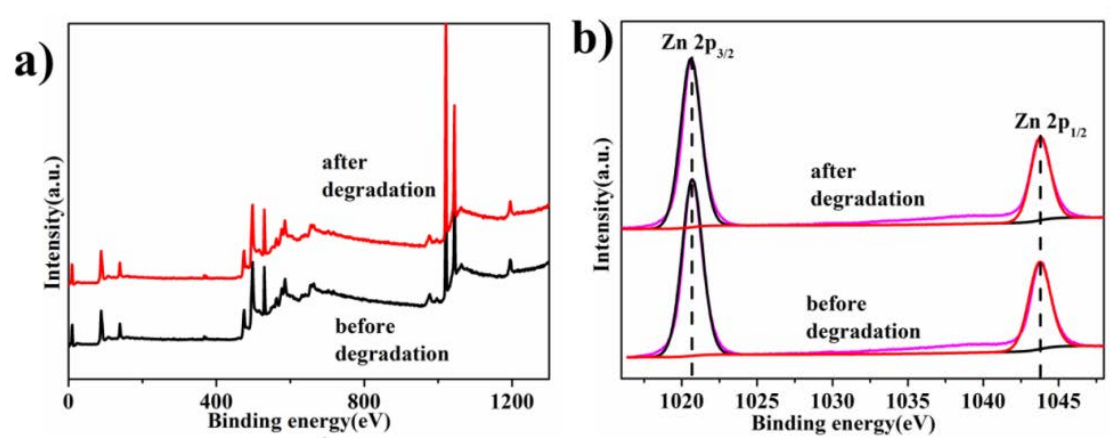
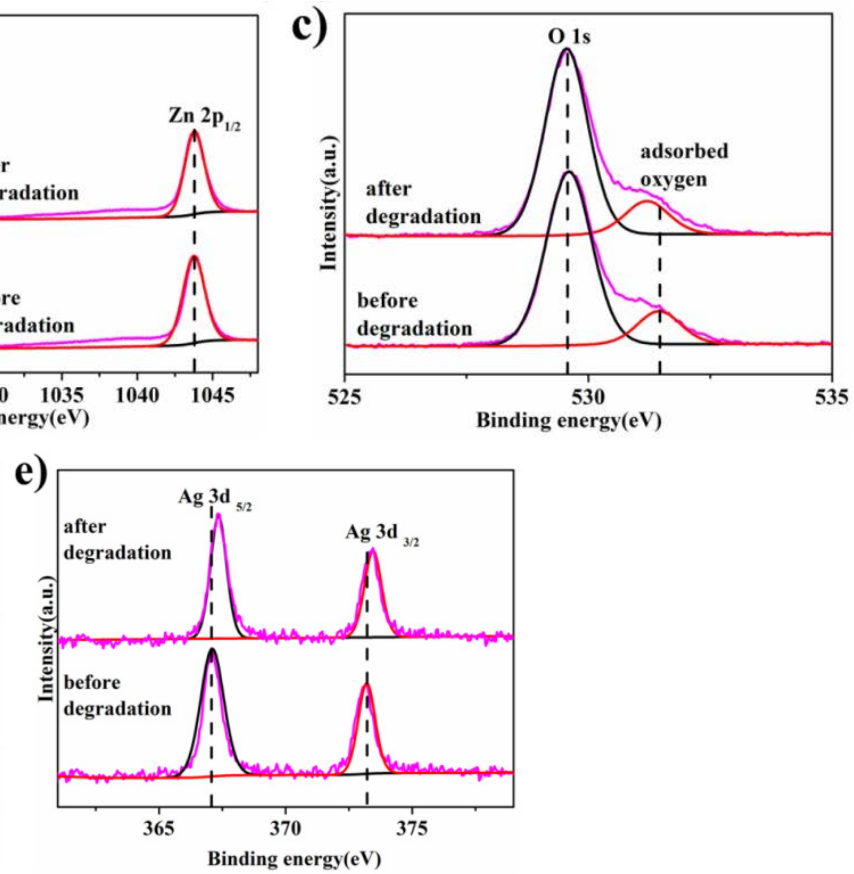

Fig. 5. (a) XPS survey spectra and (b-e) high-resolution XPS spectra of Zn 2p, $01 s$, Au $4 f$ and Ag $3 d$ for AuAg/ZnO before and after degradation.

peak of adsorbed oxygen exhibits a slightly negative shift, suggesting the chemical reactions of adsorbed $\mathrm{O}_{2}$ might be involved. In Fig. 5d, the diffraction peak located at $83.3 \mathrm{eV}$ and $88.1 \mathrm{eV}$ are corresponded to $\mathrm{Au} 4 f_{7 / 2}$ and $\mathrm{Au} 4 f_{5 / 2}$. It can be seen that the valence state does not change significantly before and after illumination, indicating the alloyed $\mathrm{Au}$ and unalloyed $\mathrm{Au}$ are very stable. But Fig. 5e shows that before the illumination, the peak positions are located at $367.1 \mathrm{eV}$ and $373.2 \mathrm{eV}$, respectively, which are features of $\mathrm{Ag}^{0}$. After the illumination, the peak position shifts slightly to the high binding energy at 367.4 $\mathrm{eV}$ and $373.5 \mathrm{eV}$ and exists a mixed state. This is because the $\mathrm{Ag}$ particles are unstable and easily lose electrons under long-time illumination. The unalloyed Ag particles lose elections and become $\mathrm{Ag}^{+}$and thus the peaks exhibited a positive shift [47]. However, the most Ag elements in AuAg alloy are still $\mathrm{Ag}^{0}$, which proves the superiority of the AuAg alloy. This result also corresponds to the test results of photocatalytic stability.

\subsection{Photocatalytic $\mathrm{C}_{2} \mathrm{H}_{4}$ oxidation and stability test of as-obtained samples}

Ethylene is used as an objective organic pollutant to measure the photocatalytic activity of the as-prepared products at $15^{\circ} \mathrm{C}$. The total experimental results are shown in Fig. S3 and Fig. 6. Firstly, the blank test of ethylene without photocatalyst is performed and we find that the pure ethylene can hardly be decomposed in the absence of photocatalyst. Therefore, all the following degradation of ethylene is due to the presence of the photocatalyst. Fig. S3a illustrates the degradation curves over pure $\mathrm{ZnO}$ and $\mathrm{Au}$ decorated $\mathrm{ZnO}$. Fig. S3b and c are the corresponding kinetics curves and reaction rate constants. It is obvious that pure $\mathrm{ZnO}$ has a poor reaction rate constant of 0.004 $\mathrm{g}^{-1} \mathrm{~min}^{-1}$. After loading with a small amount of $\mathrm{Au}$, the activity has been significantly improved and the reaction rate of $0.5 \%$ $\mathrm{Au} / \mathrm{ZnO}$ even reaches up to $0.162 \mathrm{~g}^{-1} \mathrm{~min}^{-1}$, which is 40 times that of pure $\mathrm{ZnO}$. It can be seen the existence of noble metal $\mathrm{Au}$ has a great role in promoting the activity due to its extended light absorption, which confirms our speculation exactly. Then we study the effect of Au-Ag alloy and the optimal loading amount of Ag (Fig. S3 d-f). We find that when the precursor of $\mathrm{Au}(0.5 \%)$ and $\mathrm{Ag}(0.1 \%-0.7 \%)$ are simultaneously added into the $\mathrm{ZnO}$ suspension and reduced to $\mathrm{Au}, \mathrm{Ag}$ and $\mathrm{Au}-\mathrm{Ag}$ alloy, the activity has been further upgraded. When the ratios of $\mathrm{Au}$ and $\mathrm{Ag}$ are $0.5 \%$ and $0.3 \%$ (total amount of noble metal is $0.8 \%$ ), the reaction rate reaches the highest. Then we also make a comparative experiment of $0.8 \% \mathrm{Au}$ and $0.8 \% \mathrm{Ag}$ in Fig. 6, both are less active than $\mathrm{AuAg} / \mathrm{ZnO}$. The reaction rate of $0.8 \%$ $\mathrm{AuAg} / \mathrm{ZnO}$ is approximately 5.41 and 3.54 times more than the $0.8 \% \mathrm{Au} / \mathrm{ZnO}$ and $0.8 \% \mathrm{Ag} / \mathrm{ZnO}$. Hence, it is clear that the synergistic effect of Au and Ag has unmatched superiority.

In order to compare the photocatalytic effects of our synthesized photocatalysts with other photocatalysts, the photocatalytic degradation activity of $\mathrm{AuAg} / \mathrm{ZnO}$ sample was com-

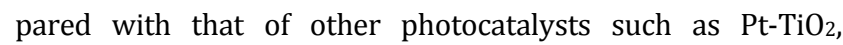
$\mathrm{Pt} @ \mathrm{Fe}-\mathrm{WO}_{3}, \mathrm{Ag} / \mathrm{AgCl} / \mathrm{TiO}_{2}, \mathrm{Ag}-\mathrm{ZnO}, \mathrm{BiVO}_{4} / \mathrm{P} 25, \mathrm{P} 25 / \mathrm{Bi}_{2} \mathrm{WO}_{6}$ and $\mathrm{In}_{2} \mathrm{O}_{3}-\mathrm{Ag}-\mathrm{Ag}_{3} \mathrm{PO}_{4}$, the detailed results are shown in Table S1. It can be seen from the roughly calculated reaction rate (ppm g-1 $\mathrm{min}^{-1}$ ) that the $\mathrm{AuAg} / \mathrm{ZnO}$ has the highest activity among many photocatalysts, which proves that $\mathrm{AuAg} / \mathrm{ZnO}$ sample has a good application prospect. In addition, we have done similar experiments using nanoflower-like $\mathrm{ZnO}$ and found that the morphology of $\mathrm{ZnO}$ did not affect the experimental rules. That is, the regularity in $\mathrm{C}_{2} \mathrm{H}_{4}$ degradation of nanoflower-like $\mathrm{ZnO}$ was similar to that of the nanorod-like $\mathrm{ZnO}$, indicating that the regularity of $\mathrm{AuAg} / \mathrm{ZnO}$ in degradation of ethylene is universal. The related comparison experiment results 

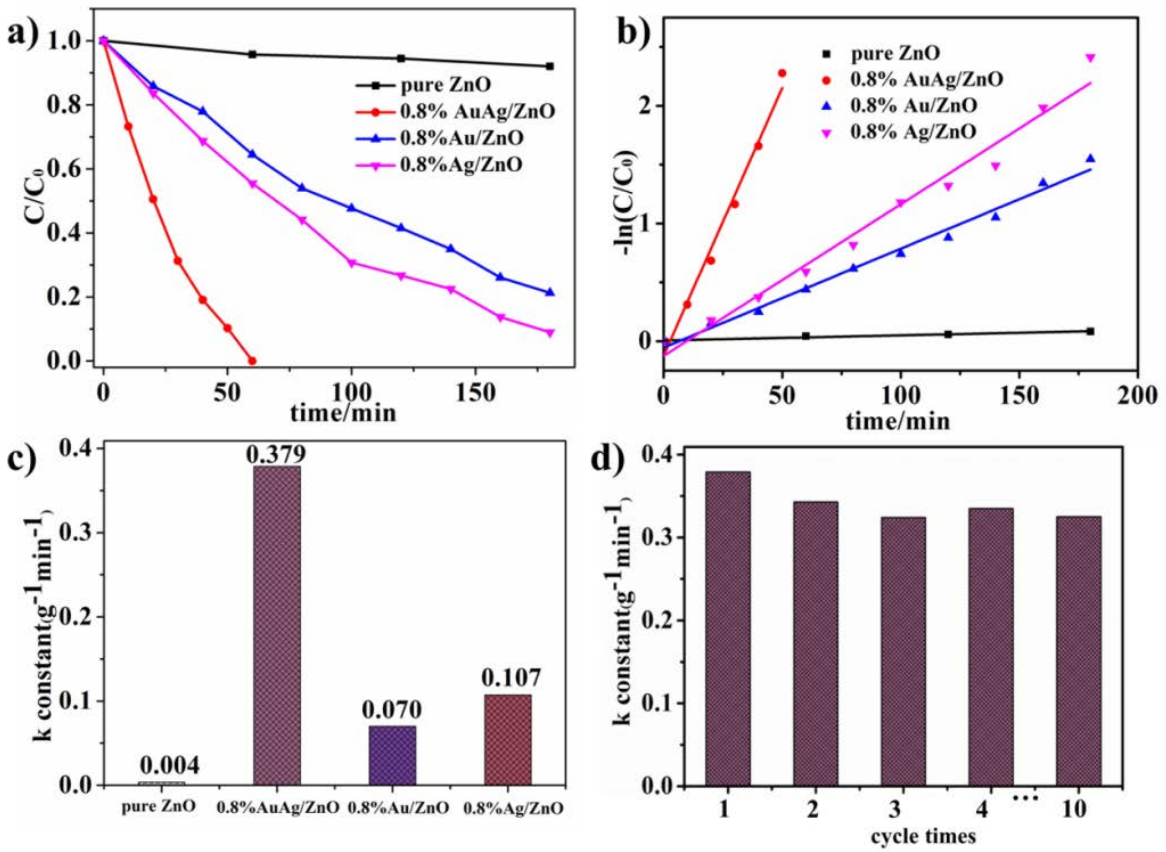

Fig. 6. (a) Comparative photodegradation activities of $\mathrm{C}_{2} \mathrm{H}_{4}$, (b) the corresponding kinetics curves, (c) the reaction rate constants of the total contrast activities of pure $\mathrm{ZnO}, 0.8 \% \mathrm{AuAg} / \mathrm{ZnO}, 0.8 \% \mathrm{Au} / \mathrm{ZnO}$ and $0.8 \% \mathrm{Ag} / \mathrm{ZnO}$ under (UV-vis) light illumination, (d) the recyclability for the photocatalytic degradation of $\mathrm{C}_{2} \mathrm{H}_{4}$ in the presence of $0.8 \% \mathrm{AuAg} / \mathrm{ZnO}$ composite.

are presented in Fig. S4.

Besides the photocatalytic behavior, the stability of the photocatalyst is another vital character in practical application. To investigate the stability of $0.8 \% \mathrm{AuAg} / \mathrm{ZnO}$, ten-test cycles were conducted under the same condition. In detail, Fig. $6 \mathrm{~d}$ is photodegradation kinetic constant of $\mathrm{C}_{2} \mathrm{H}_{4}$ of these ten-time tests. As can be seen, the photocatalytic $\mathrm{C}_{2} \mathrm{H}_{4}$ oxidation over 0.5\%Au@0.3\%Ag/ZnO shows a slight downward trend after one cycle and the rate constant drops from $0.379 \mathrm{~g}^{-1} \mathrm{~min}^{-1}$ to $0.343 \mathrm{~g}^{-1} \mathrm{~min}^{-1}$. However, there is no significant decrease of activity from the second to the tenth cycle of photocatalytic measurements, that is, the corresponding $k$ constant is 0.343 , $0.324,0.335$ and $0.325 \mathrm{~g} \mathrm{~g}^{-1} \mathrm{~min}^{-1}$, separately. The reason for this phenomenon, in our opinion, may be due to that part of the separate $\mathrm{Ag}$ is oxidized to $\mathrm{Ag}_{2} \mathrm{O}$. After one-time irradiation, the all or most isolated $\mathrm{Ag}$ is become $\mathrm{Ag}_{2} \mathrm{O}$ because of its unstable chemical properties. But the Au-Ag alloy and separate Au have no change because they are quite stable. Thus, after the first little decline, the succeeding photocatalytic activities show little

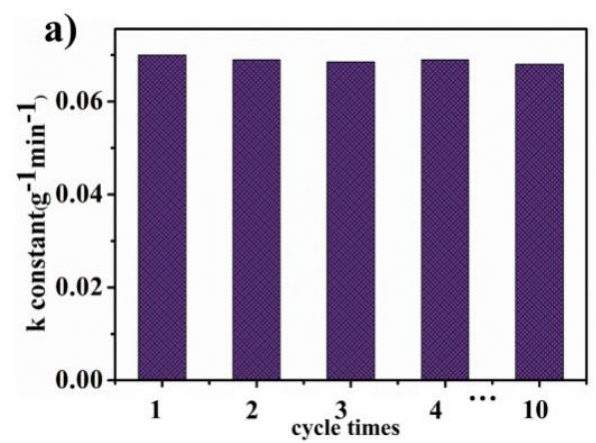

changes.

In order to verify this conjecture, the stability of single $\mathrm{Au} / \mathrm{ZnO}$ and $\mathrm{Ag} / \mathrm{ZnO}$ has also been studied (Fig. 7a and b). It can be seen that the $\mathrm{Au} / \mathrm{ZnO}$ has very great stable activity. After ten times of circulations, the reaction rates are almost unchanged. However, it is interesting to see that the $\mathrm{Ag} / \mathrm{ZnO}$ has a relatively poor stability. The reaction rate drops to almost half after the first cycle and attenuates in the following tests. When going to the tenth cycle, the reaction rate is close to one tenth of the first. This result just verifies our conjecture that isolated $\mathrm{Ag}$ is not stable while $\mathrm{Ag}$ in the $\mathrm{Au}-\mathrm{Ag}$ alloy is quite stable. These results demonstrate the $\mathrm{Au}-\mathrm{Ag}$ alloy exhibits good stability compared to the separate Ag and exhibits great activity compared to the separate Au. Above all, the Au-Ag alloy supported on the $\mathrm{ZnO}$ nanorods has unparalleled excellence.

To examine the mineralization ratio of ethylene oxidation, the photocatalytic measurement over the $\mathrm{AuAg} / \mathrm{ZnO}$ product is further conducted in Fig. 8. At beginning, the concentration of $\mathrm{C}_{2} \mathrm{H}_{4}$ and $\mathrm{CO}_{2}$ is $1250 \mathrm{ppm}$ and 0 ppm (the 0 ppm is after de-

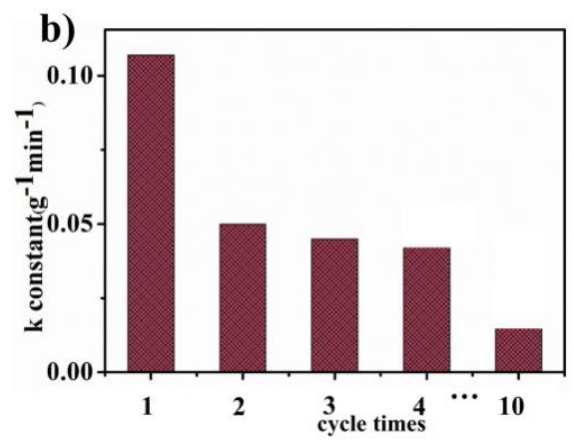

Fig. 7. The recyclability for the photocatalytic degradation of $\mathrm{C}_{2} \mathrm{H}_{4}$ in the presence of (a) single Au and (b) single Ag under (UV-visible) light illumination. 


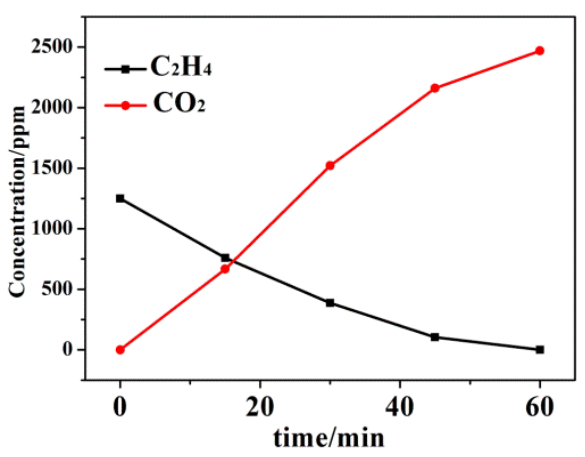

Fig. 8. Photocatalytic $\mathrm{C}_{2} \mathrm{H}_{4}$ degradation and $\mathrm{CO}_{2}$ generation of $\mathrm{AuAg} / \mathrm{ZnO}$.

ducting the $\mathrm{CO}_{2}$ content in the air), respectively. When the light is turned on, the concentration of $\mathrm{C}_{2} \mathrm{H}_{4}$ rapidly decreases to zero in $1 \mathrm{~h}$, meanwhile, the concentration of $\mathrm{CO}_{2}$ increases with two times of $\mathrm{C}_{2} \mathrm{H}_{4}$ reducing. Finally, the concentration of $\mathrm{CO}_{2}$ is 2467 ppm (about 2500 ppm). The result confirms that ethylene oxidation is truly driven by a photocatalytic process, and $\mathrm{C}=\mathrm{C}$ bond in $\mathrm{C}_{2} \mathrm{H}_{4}$ is almost broken into two times of $\mathrm{O}=\mathrm{C}=0$ bond. The mineralization ratio of ethylene is about $100 \%$ in this reaction.

\subsection{Photoelectrochemical measurements}

The strong capacity of charge migration can be certified by the enlarged photocurrent $[49,50]$. Just like the results of photocatalytic activities, the photocurrents of these products have the same discipline. As shown in Fig. 9, pure ZnO has a very poor photoelectric response, which means that the electrons and holes in $\mathrm{ZnO}$ are easily recombined under light irradiation. Surprisingly, $\mathrm{Au} / \mathrm{ZnO}$ and $\mathrm{Ag} / \mathrm{ZnO}$ all have the enhanced photocurrent as expected, which signifies that $\mathrm{Au}$ and Ag acting as electronic capture centers are beneficial to effective charge-transfer process. On the other hand, by combining $\mathrm{Au}$ and Ag NPs with ZnO, the plasmon-excited electrons can be injected into $\mathrm{ZnO}$ and make it visible light active, resulting in stronger photocurrent. Then just as we thought, the photocurrent intensity of $\mathrm{AuAg} / \mathrm{ZnO}$ is futher increased compared with that of single $\mathrm{Au}$ or $\mathrm{Ag}$ deposited on $\mathrm{ZnO}$, indicating the synergy effect of Au-Ag alloy can excite more electrons and they have

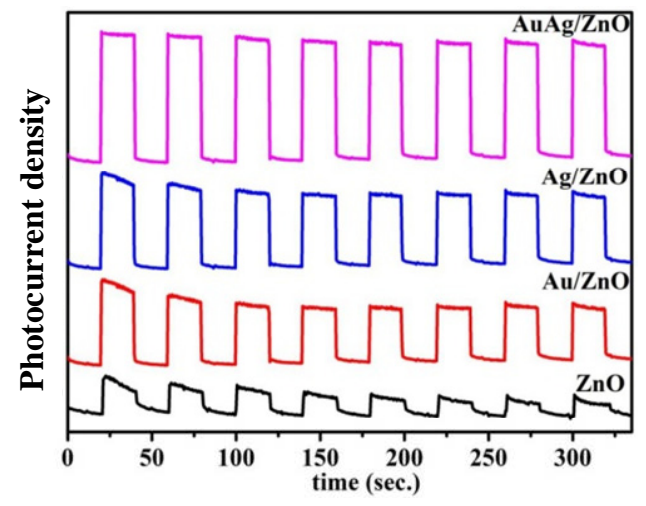

Fig. 9. Transient photocurrent response of pure $\mathrm{ZnO}, \mathrm{Au} / \mathrm{ZnO}, \mathrm{Ag} / \mathrm{ZnO}$ and the AuAg/ZnO composites under (UV-visible) light illumination. the function to accelerate the separation of charge carriers further more. The above results show that the Au-Ag alloy has good synergy effect to have a prolonged recombination time and enhanced photocurrent density.

\subsection{Mechanism study}

Based on the above results, a feasible reaction mechanism is proposed in Fig. 10. As we know, $\mathrm{ZnO}$ is a semiconductor with a wide band gap of $3.1 \mathrm{eV}$, which can only absorb the UV light. Thus, the ZnO cannot be excited by visible light. Nevertheless, $\mathrm{Au}$ and $\mathrm{Ag}$ have good absorption in the visible light area due to their special surface plasmon resonance (SPR) [15-19]. Because the conduction band position of $\mathrm{ZnO}(-0.31 \mathrm{eV}$ vs NHE) is more negative than $E_{0}\left(\mathrm{O}_{2} / \cdot \bullet_{2}-\right)(-0.046 \mathrm{eV}$ vs $\mathrm{NHE})$, the process of the single-electron reduction of oxygen can proceed and generate $\bullet \mathrm{O}_{2}{ }^{-}$[50]. Hence, the plasmon-induced electrons in the $\mathrm{Au}, \mathrm{Ag}$ and $\mathrm{Au}-\mathrm{Ag}$ alloy NPs can migrate to the $\mathrm{CB}$ of $\mathrm{ZnO}$ through the metals- $\mathrm{ZnO}$ interface. These electrons can produce $\cdot \mathrm{O}_{2^{-}}$and be used for the degradation of $\mathrm{C}_{2} \mathrm{H}_{4}$. Details of the mineralization process of ethylene and the reactions are given in Fig. 10. It is worth mentioning that the reaction efficiency under visible light is very low because the number of plasmon-induced electrons is very small compared to those photoexcited electrons in $\mathrm{ZnO}$. The corresponding irradiations were performed with filtered visible light $(\lambda>420 \mathrm{~nm})$ in Fig. S5. We find that there is no capacity of pure $\mathrm{ZnO}$ to degradate $\mathrm{C}_{2} \mathrm{H}_{4}$ under the visible light while the $\mathrm{AuAg} / \mathrm{ZnO}$ has a certain performance that can degrade half of the ethylene in $24 \mathrm{~h}$. When the light source is UV-visible light, the AuAg/ZnO can absorb both visible and UV light. On the one hand, $\mathrm{Au}, \mathrm{Ag}$ and $\mathrm{Au}-\mathrm{Ag}$ can absorb the visible light and induce the plasmon-excited electrons $\mathrm{e}^{-}$AuAg. On the other hand, the $\mathrm{ZnO}$ body can be excited by ultraviolet light to produce photogenerated electrons $\mathrm{e}^{-} \mathrm{CB}$. More importantly, the $\mathrm{Au}, \mathrm{Ag}$ and $\mathrm{Au}-\mathrm{Ag}$ NPs serve as electronic capture center, which can receive electrons from the conduction band of $\mathrm{ZnO}$ and prolong the life of electrons. These two types of electrons work together so that the reaction rate at full arc light is much greater than that under visible light. In addition, the synergy of $\mathrm{Au}$ and $\mathrm{Ag}$ is another important reason of

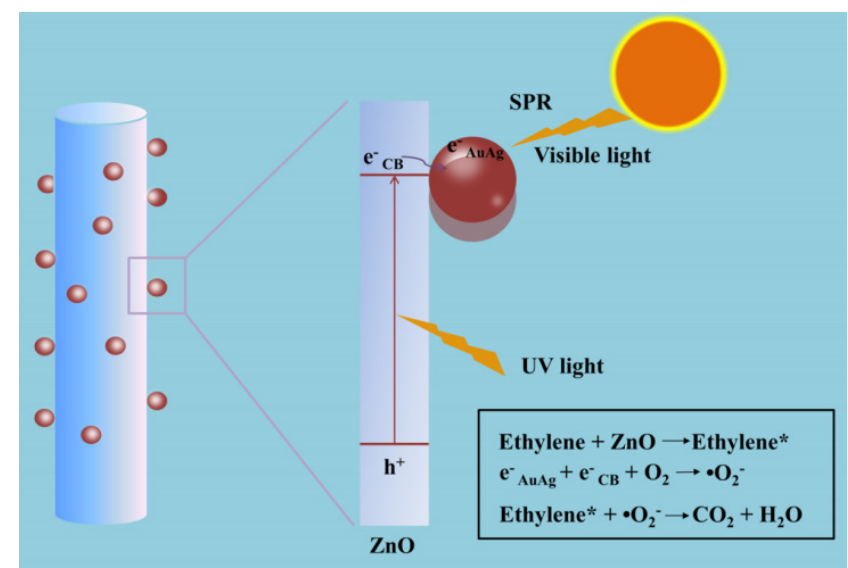

Fig. 10. Pictographic representation and the possible mechanisms of the excitation of surface plasmon and electron transfer process during the irradiation of UV-visible light. 
good activity. In a word, the overall high photocatalytic activity of Au-Ag NPs loaded $\mathrm{ZnO}$ in gaseous pollutants oxidation can be ascribed to efficient visible light absorption by Au-Ag alloy NPs, synergistic effects of SPR excitation and electronic captures of $\mathrm{Au}-\mathrm{Ag}$ NPs.

\section{Conclusions}

The phenomenon presented here shows that $\mathrm{Au}$ and $\mathrm{Ag}$ co-loaded $\mathrm{ZnO}$ sample in the suitable $\mathrm{Au} / \mathrm{Ag}$ ratio is an outstanding product for the solar-light oxidation of $\mathrm{C}_{2} \mathrm{H}_{4}$ to $\mathrm{CO}_{2}$. Among them, the photocatalytic ethylene oxidation of $0.8 \%$ $\mathrm{AuAg} / \mathrm{ZnO}$ is approximately 94.75, 5.41 and 3.54 times more than that of pure $\mathrm{ZnO}, 0.8 \% \mathrm{Au} / \mathrm{ZnO}$ and $0.8 \% \mathrm{Ag} / \mathrm{ZnO}$. These data also appear that highly efficient photocatalytic activity is related to the synergistic effects of $\mathrm{Au}-\mathrm{Ag}$ based on their special SPR excitation. Therefore, the co-deposition of plasmonic $\mathrm{Au}-\mathrm{Ag}$ bimetallic alloy on semiconductor provides a new route on better utilizing a wide range of solar spectrum.

\section{References}

[1] T. K. San, A. L. Rogach, F. J. Ckel, T. A. Klar, J. Feldmann, Adv. Mater, 2010, 22, 1805-1825.

[2] P. K. Jain, X. H. Huang, I. H. El-Sayed, M. A. El-Sayed, Acc. Chem. Res., 2008, 41, 1578-1586.

[3] Y. Q. Wu, P. Wang, X. L. Zhu, Q. Q. Zhang, Z. Y. Wang, Y. Y. Liu, G. Z. Zou, Y. Dai, M. H. Whangbo, B. B. Huang, Adv. Mater., 2018, 30, 1704342.

[4] Y. Q. Wu, P. Wang, Z. H. Guan, J. X. Liu, Z. Y. Wang, Z. K. Zheng, S. Y. Jin, Y. Dai, M. H. Whangbo, B. B. Huang, ACS Catal., 2018, 8, 10349-10357.

[5] X. Z. Liang, P. Wang, M. M. Li, Q. Q. Zhang, Z. Y. Wang, Y. Dai, X. Y. Zhang, Y. Y. Liu, M. H. Whangbo, B. B. Huang, Appl. Catal. B: Environ., 2018, 220, 356-361.

[6] X. Z. Liang P. Wang, B. B. Huang, Q. Q. Zhang, Z. Y. Wang, Y. Y. Liu , Z. K. Zheng, X. Y. Qin, X. Y. Zhang, Y.Dai, J. Mater. Chem. A, 2019, 7, $1647-1657$.

[7] H. L. Zheng, Z. Y. Jiang, H. S, Zhai, Z. K. Zheng, P. Wang, Z. Y. Wang, Y. Y. Liu, X. Y. Qin, X. Y. Zhang, B. B. Huang, Appl. Catal. B: Environ.,
2019, 243, 381-385.

[8] Z. H. Guan, Y. Q. Wu, P. Wang, Q. Q. Zhang, Z. Y. Wang, Z. K. Zheng, Y. Y. Liu, Y. Dai, M. H. Whangbo, B. B. Huang, Appl. Catal. B: Environ., 2019, 245, 522-527.

[9] J. J. Wu, C. H. Tseng, Appl. Catal. B: Environ., 2006, 66, 51-57.

[10] H. J. Yan, J. H. Yang, G. J. Ma, G. P. Wu, X. Zong, Z. B. Lei, J. Y. Shi, C. Li, J. Catal., 2009, 266, 165-168.

[11] T. Kamegawa, S. Matsuura, H. Seto, H. Yamashita, Angew. Chem. Int. Ed., 2013, 52, 916-919.

[12] G. Gao, Y. Jiao, E. R. Waclawik, A. Du, J. Am. Chem. Soc., 2016, 13, 6292-6297.

[13] Y. Zhang, N. Zhang, Z. R. Tang, Y. J. Xu, ACS Sustain. Chem. Eng., 2013, 1, 1258-1266.

[14] X. Y. Pan, Y. J. Xu, ACS Appl. Mater. Interfaces, 2014, 6, 1879-1886.

[15] A. Tanaka, K. Hashimoto, H. Kominami, J. Am. Chem. Soc., 2014, 136, 586-589.

[16] P. Wang, B. Huang, X. Qin, X. Zhang, Y. Dai, J. Wei, M. Whangbo, Angew. Chem. Int. Ed., 2008, 47, 7931-7933.

[17] S. Mukherjee, F. Libisch, N. Large, O. Neumann, L. V. Brown, J. Cheng, J. B. Lassiter, E. A. Carter, P. Nordlander, N. J. Halas, Nano Lett., 2013, 13, 240-247.

[18] A. Tanaka, K. Nakanishi, R. Hamada, K. Hashimoto, H. Kominami, ACS Catal., 2013, 3, 1886-1891.

[19] A. Tanaka, Y. Nishino, S. Sakaguchi, T. Yoshikawa, K. Imamura, K. Hashimoto, H. Kominami, Chem. Commun., 2013, 49, 2551-2553.

[20] H. B. He, S. S. Xue, Z. Wu, C. L. Yu, K. Yang, G. M. Peng, W. Q. Zhou, D. H. Li, Chin. J. Catal., 2016, 37, 1841-1580.

[21] K. Yang, X. X. Li, C. L. Yu, D. B. Zeng, F. Y. Chen, K. L. Zhang, W. Y. Huang, H. B. Ji, Chin. J. Catal., 2019, 40, 796-818.

[22] J. Tian, R. Y. Liu, Z. Liu, C. L.Yu, M. C. Liu, Chin. J. Catal., 2017, 38, 1999-2008.

[23] C. L. Yu, H. B. He, X. Q. Liu, J. L. Zeng, Z. Liu, Chin. J. Catal., 2019, 40, 1212-1221.

[24] W. Li, C. Feng, S. Dai, J. Yue, F. Hua, H. Hou, Appl. Catal. B: Environ., 2015, 168, 465-471.

[25] C. Y. Hu, X. Chen, J. B. Jin, Y. Han, S. M. Chen, H. X. Ju, J. Cai, Y. R. Qiu, C. Gao, C. M. Wang, Z. M. Qi, R. Long, L. Song, Z. Liu, Y. J. Xiong, J. Am. Chem. Soc., 2019, 141, 7807-7814.

[26] Y. N. Li, L. Wang, J. X. Low, D. Wu, C. Y. Hu, W. B. Jiang, J. Ma, C. M. Wang, R. Long, L. Song, H. X. Xu, Y. J. Xiong, Chin. Chem. Lett., 2019, DOI:10.1016/j.cclet. 2019.04.022.

[27] R. Long, Y. Li, Y. Liu, S. M. Chen, X. S. Zheng, C. Gao, C. H. He, N. S.

\section{Graphical Abstract}

Chin. J. Catal., 2020, 41: 1613-1621 doi: S1872-2067(19)63473-X

\section{ZnO nanorod decorated by Au-Ag alloy with greatly increased} activity for photocatalytic ethylene oxidation

Huishan Zhai, Xiaolei Liu, Zeyan Wang, Yuanyuan Liu, Zhaoke Zheng, Xiaoyan Qin, Xiaoyang Zhang, Peng Wang *, Baibiao Huang * Shandong University

$\mathrm{Au}-\mathrm{Ag}$ alloy NPs were loaded on $\mathrm{ZnO}$ by photo-deposition procedure with high photocatalytic activity and stability, which can be ascribed to efficient visible light absorption by AuAg alloy NPs and synergistic effects of LSPR excitation.

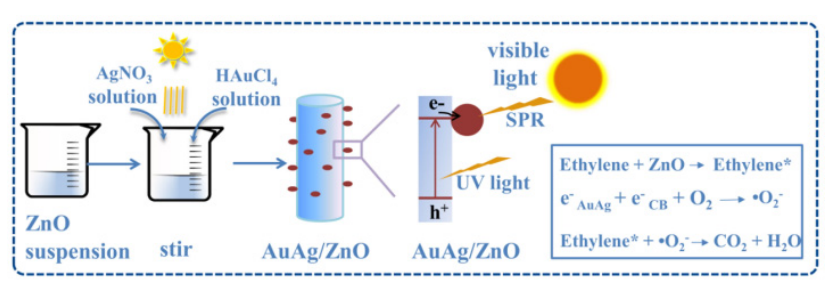


Chen, Z. M. Qi, L. Song, J. Jiang, J. F. Zhu, Y. J. Xiong, J. Am. Chem. Soc., 2017, 139, 448-4492.

[28] W. Ye, S. M. Chen, M. S. Ye, C. H. Ren, J. Ma, R. Long, C. M. Wang, J. Yang, L. Song, Y. J. Xiong, Nano Energy, 2017, 39, 532-538.

[29] M. Q. Li, N. Zhang, R. Long, W. Ye, C. M. Wang, Y. J. Xiong, Small, 2017, 13, 1604173.

[30] S. Neatu, J. A. Macia-Agullo, P. Concepcion, H. Garcia, J. Am. Chem. Soc., 2014, 136, 15969-15976.

[31] A. Wang, Y. P. Hsieh, Y. F. Chen, C. Y. Mou, J. Catal., 2006, 237, 197-206.

[32] M. Tahir, B. Tahir, N. A. S. Amin, Appl. Catal. B: Environ., 2017, 204, 548-560.

[33] Q. Wang, X. Wang, M. Zhang, G. Li, S. Gao, M. Y. Li, Y. Q. Zhang, J. Colloid Interface Sci., 2016, 463, 308-316.

[34] C. H. Han, X. Z. Yang, G. J. Gao, J. Wang, H. L. Lu, J. Liu, M. Tong, X. Y. Liang, Green Chem., 2014, 16, 3603-3615.

[35] M. E. Saltveit, Postharvest Biol. Technol., 1999, 15, 279-292.

[36] N. Keller, M. Ducamp, D. Robert, V. Keller, Chem. Rev., 2013, 113, 5029-5070.

[37] A. D. Belapurkar, V. S. Kamble, G. R. Dey, Mater. Chem. Phys., 2010, 123, 801-805.

[38] S. Kumar, A. G. Fedorov, J. L. Gole, Appl. Catal. B: Environ., 2005, 57, 93-107.

[39] D. Z. Li, H. J. Huang, X. Chen, Z. X. Chen, W. J. Li, D. Ye, X. J. Fu, Solid
State Chem., 2007, 180, 2630-2634.

[40] H. N. Huang, H. L. Li, Z. Y. Wang, P. Wang, Z. K. Zheng, Y. Y. Liu, Y. Dai, Y. J. Li, B. B. Huang, Chem. Eng. J., 2019, 361, 1089-1097.

[41] S. M. Thalluri, M. G. Saracco, J. Barber, N. Russo, Ind. Eng. Chem. Res., 2014, 53, 2640-2646.

[42] X. X. Chen, R. Li, X. Y. Pan, X. T. Huang, Z. G. Yi, Chem. Eng. J., 2017, $320,644-652$.

[43] X. L. Liu, H. S. Zhai, P. Wang, Q. Q. Zhang, Z. Y. Wang, Y. Y. Liu, Y. Dai, B. B. Huang, X. Y. Qin, X. Y. Zhang, Catal. Sci. Technol., 2019, 9, 652-658.

[44] Y. Zheng, L. Zheng, Y. Zhan, X. Lin, Q. Zheng, K. Wei, Inorg. Chem., 2007, 46, 6980-6986.

[45] P. Dong, B. Yang, C. Liu, F. Xu, X. Xi, RSC Adv., 2017, 7, 947-956.

[46] S. Samanta, S. Martha, K. Parida, ChemCatChem, 2014, 6, 1453-1462.

[47] J. Liu, S. Zou, L. Xiao, J. Fan, Catal. Sci. Technol, 2014, 4, 441-446.

[48] Y. An, Y. Y. Liu, P. F. An, J. C. Dong, B. Y. Xu, Y. Dai, X. Y. Qin, X. Y. Zhang, M. H. Whangbo, B. B. Huang, Angew. Chem. Int. Ed., 2017,129, 3082-3086.

[49] G. Wang, B. B. Huang, X. C. Ma, Z. Y. Wang, X. Y. Qin, X. Y. Zhang, Y. Dai, M. H. Whangbo, Angew. Chem. Int. Ed., 2013, 52, 4810-4813.

[50] L. Q. Ye, J. Y. Liu, C, Q. Gong, L. H. Tian, T. Y. Peng, L. Zan, ACS Catal., 2012, 2, 1677-1683.

\title{
贵金属Au-Ag合金修饰ZnO用于光催化高效降解乙烯
}

\author{
翟慧珊, 刘小磊, 王泽岩, 刘媛媛, 郑昭科, 秦晓燕, 张晓阳, 王 朋*, 黄柏标 ${ }^{2}$ \\ 山东大学晶体材料国家重点实验室, 山东济南250100
}

\begin{abstract}
摘要: 乙烯是一种植物激素, 可以促进水果和蔬菜在生长过程中成熟, 然而在水果和蔬菜成熟之后, 源源不断产生的乙烯 会加速它们的衰老和腐烂, 不利于水果和蔬菜的则存和保鲜. 考虑到现实因素, 直接在储存环境中去除乙烯很有必要, 而 光催化技术操作简单易行, 在降解乙烯方面具有应用前景. 我们发现 $\mathrm{ZnO}$ 具有降解乙烯的作用, 但纯ZnO由于光吸收范围 窄及载流子分离效率低, 使得其降解乙烯的效果不佳. 而金、银纳米颗粒由于其表面的等离子体共振效应, 可以增强半导 体的光吸收, 同时贵金属颗粒还可以充当捕获电子的活性位点, 加快电子和空穴分离, 提高光催化效率. 因此, 将金或银作 为 $\mathrm{ZnO}$ 的助催化剂可能是提高 $\mathrm{ZnO}$ 催化性能的有效途径. 一些研究还发现, 使用双金属合金作为助催化剂可以达到比单一 金属更优越的效果. 因此在本论文中, 我们采用简单的光沉积工艺和低温敾烧方法合成了 $\mathrm{Au}, \mathrm{Ag}$ 和 $\mathrm{Au}-\mathrm{Ag}$ 合金负载的 $\mathrm{ZnO}$, 研究了它们对ZnO光催化效率的促进作用.

活性测试表明, 在 $\mathrm{ZnO}$ 负载了单独的 $\mathrm{Au}$ 或 $\mathrm{Ag}$ 颗粒后, 乙烯降解效率分别是纯ZnO的17.5和26.8倍, 光催化活性大幅增 加. 而当ZnO成功负载Au-Ag合金后, 光催化活性进一步提高到纯ZnO的94.8倍. 紫外-可见光谱结果表明, 由于表面等离子 体共振(SPR)效应, Au-Ag合金改性后的ZnO显示出很强的可见光吸收. 同时, 较高的光电流密度表明 AuAg/ZnO具有有效 的载流子分离能力. 因此, 等离子体Au-Ag双金属合金纳米粒子的协同作用和有效的载流子分离能力共同带来了乙烯氧化 的优异光催化活性. 催化剂稳定性测试表明, $\mathrm{Ag} / \mathrm{ZnO}$ 的光催化稳定性非常差, 在 10 次循环后活性下降很多, 而 $\mathrm{Au} / \mathrm{ZnO}$ 和 $\mathrm{AuAg} / \mathrm{ZnO}$ 在 10 次循环后光催化稳定性非常好. 结合XPS分析可知, $\mathrm{Ag}$ 单质颗粒可以容易地光氧化成为 $\mathrm{Ag}_{2} \mathrm{O}$, 造成活性降 低, 而Au-Ag由于形成了合金结构, 不易被氧化, 因而变得异常稳定. 最终我们得到了高活性、高稳定性的AuAg/ZnO光催化 剂. 这项工作提出了在实际生产中使用金属合金作为助催化剂去除乙烯的新思路, 具有良好的应用前景.
\end{abstract}

关键词: 等离子体共振效应; $\mathrm{Au}-\mathrm{Ag}$ 合金; 协同效应; 高效载流子分离

收稿日期: 2020-02-17. 接受日期: 2020-03-26. 出版日期: 2020-10-05.

*通讯联系人. 电话: (0531)88366139; 传真: (0531)88365969; 电子信箱: pengwangicm@sdu.edu.cn

\#通讯联系人. 电子信箱: bbhuang@sdu.edu.cn

基金来源：国家自然科学基金(51602179, 21333006, 21573135, 11374190); 泰山学者特聘专家计划.

本文的电子版全文由Elsevier出版社在ScienceDirect上出版(http://www.sciencedirect.com/science/journal/18722067). 